\title{
A GIS-based AHP Method for Groundwater Potential Zone Assessment: A Review
}

\author{
Wassfi H. Sulaiman*, Hazhir Karimi, Yaseen Taha Mustafa \\ ${ }^{l}$ Department of Environmental Science, Fuclty of Science, Univerosty of Zakho, Zakho, Kurdistan Region, Iraq, \\ (wassfi.sulaiman,hazhir.karimi, yaseen.mustafa)@uoz.edu.krd \\ *Correspondence: Wassfi.sulaiman@uoz.edu.krd
}

\begin{abstract}
Scientific and academic researches and studies trying to present a multi-range of techniques and methods focusing on groundwater pollution, potentials, assessment, and prediction, Groundwater is the most important resource of fresh water now and many researchers trying to cover all about this resource to get sustainable development. This review aims to create an overview of groundwater analysis and forecasting methods. The study is based on the need to select and group research papers into best-defined methodological categories. The article gives an overview of recent advancements in groundwater potential zone analysis approaches, as well as ongoing research objectives based on that overview. This review has overviewed papers and researches been published last decade $2010-2020$ have been done depending on the data sources from the global online database, which could obtain many papers and research studying the groundwater potential zones and other aspects related to groundwater. The aim of reviewing multiple types of research and papers on determining groundwater potential zones by applying the best techniques and selecting the most suitable factors that affect groundwater potential zones.
\end{abstract}

Keywords:Groundwater-potential zone; Multi-criteria decision making; GIS; Analytic hierarchy process $(A H P)$

Received: November 07 ${ }^{\text {th }}, 2021$ / Accepted: December 27 th 2021 / Online: December $29^{\text {th }}, 2021$

\section{Introduction}

Groundwater is an essential freshwater resource for the sustainability of daily life in urban and suburban areas as the request for freshwater increases rapidly. The influence on groundwater is highlaffectingng the environment in general. The quantity, quality, and pollution of groundwater is crucial reason to study groundwater potential zones. Population growth, irrigation demands for agriculture purposes, and the change of the climate are the main factors that make the demand for freshwater increase regularly. (Okello, Tomasello, et al. 2015) The hazards of surface water pollution, rapid climate changes in addition to the risk of droughts made urgent attention to groundwater as an alternative source of fresh water. (Diamantino, Henriques et al. 2007, Alessa, Kliskey et al. 2008) In areas with a semi-arid climate and environment, the groundwater becomes an important alternative source of freshwater, the main reason that makes groundwater much demanded and the vital source is less polluted than surface water sources, which can be polluted easily by man activities such as industrial and agricultural activates. However using the groundwater resource with no scientific and socio-eco planes on how to sustain it can cause a severe hazard on water resources in regions such as in Kurdistan Region of Iraq, therefore 
will affect the environment, the eco-system, agriculture, and daily life of the individuals as well. (Danielopol, Griebler, et al. 2003, De Stefano and Lopez-Gunn 2012) As a result, groundwater-discharge zones within a study area or the basin must be established with an emphasis on proper water management. While monitoring-purpose water wells can always be used to determine groundwater potential.

There are many modern and scientific methods to be used in determining the groundwater potential zones without the need for fieldwork and site-visit, such as the decision-tree model (Lee and Lee 2015) principal component analysis (PCA) (Helena, Pardo et al. 2000) and the logistic regression model (Pourtaghi and Pourghasemi 2014) Most of these methods are based on multivariate statistical techniques (Thapa, Gupta et al. 2015). The analytical hierarchy process (AHP), on the other hand, is thought to be an easy, efficient, clear, and dependable methodology. (Machiwal, Jha et al. 2011) By combining geographic information system (GIS) and remote sensing (RS) data, the AHP approach is simple to detect in a practical way. Effective factors on groundwater potential zone such as precipitation, reservoirs, land use, and soil conditions could be simply characterized as spatial information in a GIS and remote sensing techniques. As a result, combination of GIS and AHP is particularly useful for finding potential groundwater locations which is well to detecting groundwater-potential locations. (Elbeih 2015, 2018) (Senanayake, Dissanayake et al. 2016)

AHP is a technique created by Thomas L. Saaty in the early 1980s. (Saaty 1980) It was created using predetermined criteria at each phase, analyzing the weights of these factors, and matching the criteria to those used in other studies. (Saaty 2000, Guo, Zhang et al. 2008) Determine hydrological and hydrogeological factors that affect groundwater production and their impact on groundwater form, as well as develop potential groundwater maps, is achievable and desirable with the GIS techniques depending on a Multi Criteria Decision Making Analysis (MCDA). In the subject of hydrology and water resources, it has been widely employed (Guo, Zhang et al. 2008, Wang, Li et al. 2011). It has grown in prominence over the previous decade as a GIS-based mapping tool. (Tang, Zhang et al. 2018). The majority of recent research have successfully used RS and GIS-based AHP approaches for the estimation of water potential zones (GWPZs). (Chen, Wood et al. 2011, Abrams, Ghoneim et al. 2018, Patra, Mishra et al. 2018, Nair, Srinivas et al. 2019) Through these conducted latest studies has been found that several main and effective factors involved directly in most of them. These factor or parameters found were the land use (LU), DEM, rainfall $(\mathrm{RF})$, slope (SL), surface water body (SW), geomorphology (GM), geology (G), recharge rate (RR), drainage density (DD), lithology (LI), and water table depth (WTD). (Gupta and Srivastava 2010, Gdoura, Anane et al. 2015) By combination all factors and their weights with AHP method, the basins' groundwater potential index (GWPI) results could be determined. Following that, the GWPI data were categorized, and GWPZ maps of various regions were constructed. (Murthy 2000, Rahmati, Samani et al. 2015, IbrahimBathis and Ahmed 2016, Pinto, Shrestha et al. 2017) Furthermore, the thematic layer used to identify GWPZs vary with each study and locale, and the qualitative layers are chosen at random. Most of latest studies depended on the LU, Soil, GM, DD, SL as a main factors or parameters within the GIS systems based on AHP and MCDA. Adding parameter or the number of the dependable factors to the GIS system depends on the region of the study and the purpose of the study but in general the increasing of factors mostly will get higher accuracy results within the AHP and MCDA.

In other similar research depended on other algorithm for example frequency ratio FR in combine with AHP for example a study conducted in Turkey with a title of (GIS-Based Groundwater Potentiality Mapping Using AHP and FR Models in Central Antalya, Turkey) by (Hemayatullah Ahmadi, Ozumcan Alara Kaya, Ebru Babadagi ,Turan Savas and Emrah Pekkan 2021). In a parallel study carried out in Ethopian rift, a result from AHP technigues showed 79.9\%. Depeinding on same factors estimated the potential zones to very high to high zones in semi-arid areas. (Abrar, Legesse Kura et al. 2021)

\section{Methods and Materials}

Going through many research papers and articles that have been done on determining the groundwater potential zone index for a specific area, there are many researches and case studies used GIS based AHP and MCDA techniques in addition to some other GIS based techniques. 
This review has been done according to guidelines literature review analyses to obtain research's aims. Information and published data has been collected online through global searching engine such as Researchgate, Scopus, and Springer. Keyword have been used in the systematic review includes; groundwater, GIS and remote sensing, AHP, MCDA, Groundwater potential Zone Index (GPWI), spatial modeling and thematic. Over 23 papers have been downloaded and scanned regarded groundwater potential zone index and only 11 been selected to be reviewed within this systematic review after have been well studied. These papers and researches been published between 2009 and 2020. As it has been explained in the introduction, the groundwater is affected by multiple factors and parameters, these factors were used into GIS based AHP as a method of MCDA and other techniques to determine the groundwater potential zone index then resulted general groundwater thematic map. The study areas of the reviewed papers include wide deferent regions from the world with the differences in the climate, topography and socio-economics.

In this study 11 papers were reviewed most of them were after 2010 , this led to the using of GIS based AHP and MCDA techniques to determine groundwater and its affecting factors is getting more attention last few years. From the introduction and researchers previous studies, we can find many factors to be involved in the process of AHP and MCDA within the GPS environment. The factors used in the literature mainly founded from previous studies, books, expert opinions and etc. sometimes less or more factors were used but there are some essentials ones which are very important in order to get the precise groundwater potential zone index. Selecting the type of the factors and the numbers of them, depend mainly on the purpose of the study and the nature of the studied areas.

\section{Prepare Your Paper Before Styling}

Before you begin to format your paper, first write and save the content as a separate text file. Complete all content and organizational editing before formatting. Please note sections A-D below for more information on proofreading, spelling, and grammar.

Keep your text, and graphic files separate until after the text has been formatted and styled. Do not use hard tabs and limit the use of hard returns to only one return at the end of a paragraph. Do not add any kind of pagination anywhere in the paper. Do not number text heads-the template will do that for you.

\subsection{Factors}

From reviewed papers a repeated factors can be noticed in most of them, and widely used 8 factors only, some factors have more weight than others. Slop (1.29) is the highest effecting factor on AHP system, after that we have Rainfall factor (1.29), followed by Geomorphology (1.14), Geology (1.00), Drainage Density (1.00), Soil (1.00), Land use and Lineament Density (Çelik 2019) There may be other factors to be used within GIS based MCDA and AHP environment depending on the aim of the study and its area as has been mentioned previously.

\subsubsection{Slope}

The slope is a major topography feature that expresses the ground surface's steepness. Slope provides critical information on the nature of regional geology and geodynamic processes. (Riley 1999) Surface runoff and infiltration rates are primarily determined by the slope of the surface. The slope plays a crucial role in determining groundwater potential zones. With inadequate recharge potential, a greater level of slope leads to faster runoff and greater erosion rate. (Magesh 2012) (Magesh 2012) Slope grid is identified as "the maximum rate of change in value from each cell to its neighbors" (Burrough 1986). The slope maps mostly generated from satellite digital images of elevation DEM with a resolution of 30m and 16bit pixel depth with the aid of Arcmap10.1 and above.

\subsubsection{The rainfall}

Is the most important supply of water in the hydrological cycle, as well as the most influential element in an area's groundwater (Ibrahim-Bathis 2016) he reviewed studies generated rain full maps from monthly / annual data from regional and local authorities in the countries of the study areas e.g. meteorological departments, Agricultural Directorates and ministries. These data collected were been processed spatially 
by the Inverse Distance Weighted (IDW) technique to generate a map of average rainfall. This approximation approach follows the idea of closeness and changes occurring in the pattern area to replicate Thiessen polygons.

\subsubsection{Drainage density}

Groundwater pollution and availability are both influenced by drainage density. The drainage system is influenced by lithology and serves as an essential indicator of infiltration rate. Permeability is inversely proportional to drainage density. As a result, it is a crucial component in determining the groundwater potential zone (Ganapuram 2009)(Ganapuram 2009) obtained from DEM data, finding the length of the stream and dividing on to the total area of the basin as shown in the equation of Drainage Density $\mathrm{DD}=\mathrm{L}$ (length / A (area) and using Archydro program. (Çelik 2019). The drainage-density map was created by dividing themed river maps produced from a basin-wide flow accumulation (Fac) and stream definition operation (Çelik 2019)

\subsubsection{Geology}

In any terrain, the geologic environment plays a critical impact in the presence and distribution of groundwater (Yeh 2016) Geomorphology; Geomorphology refers to an area's landform and topography, and it's one of the most important aspects in determining groundwater potential zones. It provides data on the distribution of various landform characteristics as well as processes such as temperature variations, geochemical reactions, and water flow, freezing and thawing, and so on (Kumar 2016, Rajaveni 2017, Tapa 2017).

Geologic and Geomorphological maps created by converting length and measurement in to Km units then digitizing by Arc GIS spatial analyst program then into shp format. The geological structures were modified to raster format with the corresponding presentation, and the region's geological state was assessed. The following formula was used to compute the lineament (fault) density (LL) (Mandal, Sahoo et al. 2016):

\subsubsection{Soil}

The quantity of water that may permeate into subsurface formations and so impact groundwater recharge is influenced by soil types. (Singh 2018) (Singh 2018) (Singh 2018) In most studies samples of soil were collected from agricultural soil according to the sampling procedures. The soil samples were taken from the top $20 \mathrm{~cm}$ of four sampling location as a composite. A global positioning system (GPS) equipment is used to record the coordinates of each sample. (Schiefer et al. 2015; Filep et al. 2016; Barakat et al. 2017)

\subsubsection{Land use and land cover}

In addition to providing indications on groundwater requirements, LULC provides crucial information on infiltration (Ibrahim-Bathis 2016)(Ibrahim-Bathis 2016)moisture, groundwater, and surface water. LU and LC are the predominant coverings of the land surface by human activity or vegetation, respectively (natural or planted). On any scale, satellite imagery and remote sensing techniques may reveal this reality. During our research, we discovered that land cover appeared in four of the eleven studies.

\subsection{Groundwater Potential Zone (GWPZ)}

Groundwater is a renewable resource, but due to human activities and imbalanced development, recharging of this vital life-sustaining resource has been significantly diminished during the last 4-5 decades. This information is critical for the design and execution of structures that will enhance groundwater recharge processes. (Greene, Devillers et al. 2011) A greater knowledge of a region's groundwater potential is critical for planning and long-term development. Reviewed papers concentrate mainly of finding and estimating the GWPZ.

\subsection{GIS-Based AHP Method}

\subsubsection{GIS Geographic Information System}

A developed tool has been used widely in groundwater potential zones and assessment, it is a software and hardware combination. The combined RS-GIS analysis provides a method for reducing the number of target regions for hydrogeo-physical research. (Bagyaraj et al. 2013; Prabu and Rajagopalan 2013; 
Ndatuwong and Yadav 2014). The use of site-specific ground geophysical technologies such as very low frequency electromagnetic (VLF-EM) profiling and vertical electrical sounding (VES) for site evaluation and selection for sustainable groundwater management might then be implemented. Integration of lithology, lineament density, drainage density, geomorphology, slope, and LULC thematic layers is used in the GIS - RS spatial analysis and modeling. In terms of groundwater prospect, weights ranging from 1 to 5 were allocated to the classes in order of increasing.( Talabi and Tijani 2011) and (Fashae et al 2014).

\subsubsection{AHP Analytical Hierarchy Process}

as mentioned in the introduction it's one of the most techniques used in the MCDA approaches, this concept has been developed by Thomas L. Saaty in 1980. The AHP reviews a set of assessment criteria as well as a set of alternative possibilities from which to choose the best option that have effective weight (Saaty 1990; Malczewski 1999). It is a method for evaluating criteria weights (relative importance), various optimization techniques for each parameter, and producing an average rating of the variants that was developed by planned criteria (identification of selection criteria) at a specific stage. (Punniyamoorty, Ponnusamy et al. 2012) (Punniyamoorty, Ponnusamy et al. 2012) The AHP is commonly utilized in aspects such like minimizing issue confusion/complexity, making decisions easier, and setting priorities using specialist suggestions and evaluations. (Kannan 2010)( Kannan 2010) In all studies have been reviewed AHP were rating the parameters or factors in order to obtain each factor's weight, there should be at least 2 criteria and 2 substitutions. (Greene, Devillers et al. 2011) (Greene, Devillers et al. 2011) (Greene, Devillers et al. 2011) These factors were given relative weight, thus knowledge and experience are especially crucial for effective evaluation and analysis. Qualitative and quantitative criteria might be used. (Triantaphyllou and Sanchez 1997) (Triantaphyllou and Sanchez 1997) In all studies been reviewed after applying AHP within the MCDA a decision matrix were generated. It gives flexible scale from 1-9 from effecting factors., field experiences and literature reviews were used to weight various parameters. Then finding the system's normalized weight and consistency ratio (CR) by some equations.

\subsection{Validation}

validation of result is very important in any study or research, most of the papers have validated their result depending on some approaches such as logistic regression (LR), random forest (RF), Gradient Boosted Decision Trees (GBDT). The existence dug-wells can give precise validation results in a comparism with AHP results. The dependability of the groundwater potential model in the form of a groundwater potential map over the researched region is established by validating the outcome with available data from the research region.

\section{Conclusion}

Papers have been reviewed showed the direct effect of the groundwater potential zone on human life and economic conditions especially in arid weather regions. Therefore many studies and researches have been done on groundwater assessment and its vulnerability last decade, using AHP techniques. The papers approved that Remote Sensing and GIS based AHP and MCDA able to be combined with other systems furthermore they showed a precise and dependable tools for assessment and finding the ground water potential zones, most papers shared same parameters to find the result of a thematic map of GWPZ, then helping in the process of the decision making.

The final thematic map obtained from a combination of some factors. The number factors is likely to be more than 5 and more, because the high quantity of factors will improve the accuracy of the results then will affect positively the decision making process.

However, more researches and studies are needed vitally to be conducted on ground water, as it's a main water source precisely in Iraq and Kurdistan region, there is arid to semi-arid climate, hazards of droughts and political and international issues about surface water sources. 


\section{References}

Okello, C.; Tomasello, B.; Greggio, N.; Wambiji, N.; Antonellini, M. (2015). Impact of population growth and climate change on the freshwater resources of Lamu Island, Kenya. Water 2015, 7, 1264-1290. [CrossRef]

Diamantino, C.; Henriques, M.J.; Oliveira, M.M.; Ferreira, J.P.L. (2007). Methodologies for pollution risk assessment of water resources systems. IAHS Publ., 310, 298.

Alessa, L.; Kliskey, A.; Lammers, R.; Arp, C.; White, D.; Hinzman, L.; Busey, R. (2008). The arctic water resource vulnerability index: An integrated assessment tool for community resilience and vulnerability with respect to freshwater. Environ. Manag., 42, 523.

Danielopol, D.L.; Griebler, C.; Gunatilaka, A.; Notenboom, J. (2003). Present state and future prospects for groundwater ecosystems. Environ. Conserv., 30, 104-130.

De Stefano, L.; Lopez-Gunn, E. (2012). Unauthorized groundwater use: Institutional, social and ethical considerations. Water Policy, [6] 14, 147-160.

Lee, S.; Lee, C.W. (2015). Application of decision-tree model to groundwater productivity-potential mapping. Sustainability, 7, 13416-13432.

Helena, B.; Pardo, R.; Vega, M.; Barrado, E.; Fernandez, J.M.; Fernandez, L. (2000). Temporal evolution of groundwater composition in an alluvial aquifer (Pisuerga River, Spain) by principal component analysis. Water Res., 34, 807-816.

Pourtaghi, Z.S.; Pourghasemi, H.R. (2014). GIS-based groundwater spring potential assessment and mapping in the Birjand Township, southern Khorasan Province, Iran. Hydrogeol. J., 22, 643-662.

Thapa, R.; Gupta, S.; Guin, S.; Kaur, H. (2017). Assessment of groundwater potential zones using multi-influencing factor (MIF) and GIS: A case study from Birbhum district, West Bengal. Appl. Water Sci., 7, 4117-4131.

Machiwal, D.; Jha, M.K.; Mal, B.C. (2011). Assessment of groundwater potential in a semi-arid region of India using remote sensing, GIS and MCDM techniques. Water Resour. Manag., 25, 1359-1386.

Yin, H.; Shi, Y.; Niu, H.; Xie, D.; Wei, J.; Lefticariu, L.; Xu, S. (2018). A GIS-based model of potential groundwater yield zonation for a sandstone aquifer in the Juye Coalfield, Shangdong, China. J. Hydrol., 557, 434-447.

Elbeih, S.F. (2015). An overview of integrated remote sensing and GIS for groundwater mapping in Egypt. Ain Shams Eng. J., $6,1-15$

Senanayake, I.P.; Dissanayake, D.M.D.O.K.; Mayadunna, B.B.; Weerasekera, W.L. (2016). An approach to delineate groundwater recharge potential sites in Ambalantota, Sri Lanka using GIS techniques. Geosci. Front., 7, $115-124$.

Saaty, T.L. The Analytic Hierarchy Process; McGrawHill: New York, NY, USA, 1980

Saaty, T.L. (2000). Fundamentals of Decision Making and Priority Theory; RWS Publications: Pittsburgh, PA, USA.

Guo, J.-Y.; Zhang, Z.-B.; Sun, Q.-Y. (2008). Applications of AHP method in safety science. J. Saf. Sci. Technol., 2 , 69-73.

Wang, Y.; Li, Z.; Tang, Z.; Zeng, G. (2011). A GIS-based spatial multi-criteria approach for flood risk assessment in the Dongting Lake Region, Hunan, Central China. Water Resour. Manag., 25, 3465-3484.

Tang, Z.; Zhang, H.; Yi, S.; Xiao, Y. (2018). Assessment of flood susceptible areas using spatially explicit, probabilistic multicriteria decision analysis. J. Hydrol., 558, 144-158.

Chen, H.; Wood, M.D.; Linstead, C.; Maltby, E. (2011). Uncertainty analysis in a GIS-based multi-criteria analysis tool for river catchment management. Environ. Model. Softw., 26, 395-405.

Nair, N.C.; Srinivas, Y.; Magesh, N.S.; Kaliraj, S. (2019). Assessment of groundwater potential zones in Chittar basin, Southern India using GIS based AHP technique. Remote Sens. Appl. Soc. Environ., 15, 100248.

Abrams, W.; Ghoneim, E.; Shew, R.; LaMaskin, T.; Al-Bloushi, K.; Hussein, S.; AbuBakr, M.; Al-Mulla, E.; Al-Awar, M.; El-Baz, F. (2018). Delineation of groundwater potential (GWP) in the northern United Arab Emirates and Oman using geospatial technologies in conjunction with Simple Additive Weight (SAW), Analytical Hierarchy Process (AHP), and Probabilistic Frequency Ratio (PFR) techniques. J. Arid Environ., 157, 77-96.

Patra, S.; Mishra, P.; Mahapatra, S.C. (2018). Delineation of groundwater potential zone for sustainable development: A case study from Ganga Alluvial Plain covering Hooghly district of India using remote sensing, geographic information system and analytic hierarchy process. J. Clean. Prod., 172, 2485-2502.

Gdoura, K.; Anane, M.; Jellali, S. (2015). Geospatial and AHP-multicriteria analyses to locate and rank suitable sites for groundwater recharge with reclaimed water. Resour. Conserv. Recycl., 104, 19-30.

Gupta, M.; Srivastava, P.K. (2010). Integrating GIS and remote sensing for identification of groundwater potential zones in the hilly terrain of Pavagarh, Gujarat, India. Water Int., 35, 233-245.

Rahmati, O.; Samani, A.N.; Mahdavi, M.; Pourghasemi, H.R.; Zeinivand, H. (2015). Groundwater potential mapping at Kurdistan region of Iran using analytic hierarchy process and GIS. Arab. J. Geosci., 8, 7059-7071.

Pinto, D.; Shrestha, S.; Babel, M.S.; Ninsawat, S. (2017). Delineation of groundwater potential zones in the Comoro watershed, Timor Leste using GIS, remote sensing and analytic hierarchy process (AHP) technique. Appl. Water Sci., 7, 503519.

Murthy, K.S.R. (2000). Ground water potential in a semi-arid region of Andhra Pradesh-A geographical information system approach. Int. J. Remote Sens., 21, 1867-1884.

Ibrahim-Bathis, K.; Ahmed, S.A. (2016). Geospatial technology for delineating groundwater potential zones in Doddahalla watershed of Chitradurga district, India. Egypt. J. Remote Sens. Space Sci., 19, 223-234.

Riley, S. J. (1999). Index that quantifes topographic heterogeneity. Internet. J. Sci. 5, 23-27. 
Receb Celik, (2019). Evaluation of Groundwater Potential by GIS-Based Multicriteria Decision Making as a Spatial Prediction Tool: Case Study in the Tigris RiverBatman-Hasankeyf Sub-Basin, Turkey, Journal of Water.

Yeh, H.-F., Cheng, Y.-S., Lin, H.-I. \& Lee, C.-H. (2016). Mapping groundwater recharge potential zone using a GIS approach in Hualian River, Taiwan. Sustain. Environ. Res. 26, 33-43.

Kumar, P., Herath, S., Avtar, R. \& Takeuchi, K. (2016). Mapping of groundwater potential zones in Killinochi area, Sri Lanka, using GIS and remote sensing techniques. Sustain. Water Resour. Manag. 2, 419-430.

Rajaveni, S. P., Brindha, K. \& Elango, L. (2017). Geological and geomorphological controls on groundwater occurrence in a hard rock region. Appl. Water Sci. 7, 1377-1389.

Tapa, R., Gupta, S. \& Reddy, D. V. (2017). Application of geospatial modelling technique in delineation of fuoride contamination zones within Dwarka Basin, Birbhum, India. Geosci. Front. 8, 1105-1114.

Mandal, U.; Sahoo, S.; Munusamy, S.B.; Dhar, A.; Panda, S.N.; Kar, A.; Mishra, P.K. (2016). Delineation of groundwater potential zones of coastal groundwater basin using multi-criteria decision making technique. Water Resour. Manag., 30, 4293-4310.

Singh, L. K., Jha, M. K. \& Chowdary, V. M. (2018). Assessing the accuracy of GIS-based Multi-Criteria Decision Analysis approaches for mapping groundwater potential. Ecol. Indic. 91, 24-37.

Ibrahim-Bathis, K. \& Ahmed, S. A. (2016). Geospatial technology for delineating groundwater potential zones in Doddahalla watershed of Chitradurga district, India. Egypt. J. Remote Sens. Sp. Sci. 19, 223-234.

Greene, R.; Devillers, R.; Luther, J.E.; Eddy, B.G. (2011). GIS-based multiple-criteria decision analysis. Geogr. Compass, 5, $412-432$.

Punniyamoorty, M.; Ponnusamy, M.; Lakshmi, G. (2012). A combined application of structural equation modeling (SEM) and analytic hierarchy process (AHP) in supplier selection. Benchmarking Int. J., 19, 70-92.

Kannan, V. (2010). Benchmarking the service quality of ocean container carriers using AHP. Benchmarking Int. J., 17, 637656.

Greene, R.; Devillers, R.; Luther, J.E.; Eddy, B.G. (2011). GIS-based multiple-criteria decision analysis. Geogr. Compass, 5, 412-432.

Triantaphyllou, E.; Sanchez, A. (1997). A sensitivity analysis approach for some deterministic multi-criteria decision making methods. Decis. Sci., 28, 151-194.

Ho, W.; Xu, X.; Dey, P.K. (2010). Multi-criteria decision making approaches for supplier valuation and selection: A literature review. Eur. J. Oper. Res., 202, 16-24.

Ahmadi, H.; Kaya, O.A.; Babadagi, E.; Savas, T.; Pekkan, E. (2021). GIS-Based Groundwater Potentiality Mapping Using AHP and FR Models in Central Antalya, Turkey. Environ. Sci. Proc., 5, 11. https://doi.org/10.3390/ IECG2020-08741. 